\title{
Response of a Mu-class glutathione $S$-transferase from black tiger shrimp Penaeus monodon to aflatoxin B1 exposure
}

\author{
Yun Wang ${ }^{1}$, Lihui Liu², Jianhua Huang ${ }^{1}$, Yafei Duan ${ }^{1}$, Jun Wang ${ }^{1}$, Mingjun Fu and Heizhao Lin ${ }^{1 *}$
}

${ }^{*}$ Correspondence:
linheizhao@163.com
${ }^{1}$ Key Laboratory of Aquatic
Product Processing,
Ministry of Agriculture,
South China Sea Fisheries
Research Institute, Chinese
Academy of Fishery Sciences,
Guangzhou 510300, People's
Republic of China
Full list of author information
is available at the end of the
article

*Correspondence: linheizhao@163.com

Key Laboratory of Aquatic

Product Processing,

Ministry of Agriculture

South China Sea Fisheries

Academy of Fishery Sciences,

Guangzhou 510300, People's

article

\begin{abstract}
Glutathione S-transferases (GSTs) are a family of multifunctional phase II enzymes that are involved in the detoxification of exogenous and endogenous compounds. In this study, a full-length cDNA of Mu-class GST (PMMUGST) was isolated from the hepatopancreas of Penaeus monodon using rapid amplification of CDNA ends method. The full length cDNA of PmMUGST is $867 \mathrm{bp}$, contains an open read frame of $660 \mathrm{bp}$, and encodes a polypeptide of 219 amino acids with a molecular mass of $25.61 \mathrm{kDa}$ and $p \mathrm{l}$ of 6.15. Sequence analysis indicated that the predicted protein sequence of PMMUGST was very similar to (86 \%) that of Litopenaeus vannamei. A conserved domain of GST_N_Mu_like (PSSM: cd03075) and GST_C_family_superfamily_like (PSSM: cl02776) was indentified in PmMuGST. Real time quantitative RT-PCR analysis indicated that PmMUGST was present in all of the tested tissues. PmMUGST transcripts both in the hepatopancreas and in the muscle were significantly induced after 14 days of treatment with a low dosage of AFB1 $(50 \mu \mathrm{g} / \mathrm{kg})$ exposure and were significantly inhibited after 42 and 56 days of a high dosage of AFB1 $(1000,2500 \mu \mathrm{g} / \mathrm{kg}$ AFB1) exposure. Taken together, the Mu-class GST from P. monodon was inducible and was involved in the response to AFB1 exposure.
\end{abstract}

Keywords: Penaeus monodon, Mu-class glutathione S-transferase, Aflatoxin B1 exposure, cDNA cloning

\section{Background}

To counteract the harmful effects of endogenous and exogenous compounds, such as drugs and mycotoxins, living organisms employ an array of enzymatic detoxification processes that have been classified into three distinct phases (Bathige et al. 2014). Enzymes in phase I and II convert xenobiotics to less toxic water-soluble metabolites, which are later eliminated from the cell via phase III enzymes (Sheehan et al. 2001). Glutathione S-transferases (GST S.C. 2.5.1.18) are the major enzymes in phase II metabolism and are involved in the detoxification process by catalyzing the conjugation of glutathione (GSH) with substrates that have an electrophilic carbon, nitrogen or sulfur atom. The substrates include halogenonitrobenzenes, arene oxides, quinones, $\alpha$ - and $\beta$-unsaturated carbonyls and aflatoxins (Hayes et al. 2005). Based on the substrate specificity, antibody cross-reactivity and sensitivity to inhibitors, GSTs from various organisms have been identified as representing at least 15 different classes (Wang et al. 2013). To date,

C 2016 The Author(s). This article is distributed under the terms of the Creative Commons Attribution 4.0 International License (http://creativecommons.org/licenses/by/4.0/), which permits unrestricted use, distribution, and reproduction in any medium, provided you give appropriate credit to the original author(s) and the source, provide a link to the Creative Commons license, and indicate if changes were made. 
many classes of GSTs have also been cloned and characterized in several aquatic species including the Pacific oyster Crassostrea gigas (Boutet et al. 2004), rock shell Thais clavigera (Rhee et al. 2008), disk abalone Haliotis discus discus (Wan et al. 2008a), yellow catfish Pelteobagrus fulvidraco (Ku et al. 2014) and Manila clam Ruditapes philippinarum (Bathige et al. 2014). Regarding aquatic crustaceans, Contreras-Vergara et al. (2004) reported the first Mu-class of GSTs in the white shrimp Litopenaeus vannamei. GSTs, as components of the detoxification mechanism in L. vannamei, function similarly to what has been observed in mammals and other invertebrates (Salazar-Medina et al. 2010; Goncalves-Soares et al. 2012). Two classes of GSTs (FcMuGST, FcThetaGST) were cloned from Chinese shrimp Fenneropenaeus chinensis, and the FcMuGST transcript was determined to be increased in response to Vibrio anguillarum infection, while FcThetaGST showed little change at the transcript level. It was speculated that FcMuGST may play a vital role in the detoxification process after $V$. anguillarum infection (Ren et al. 2009b). The theta GST from freshwater prawn Macrobrachium rosenbergii was thought to play a variety of functions such as in immune responses and detoxification (Arockiaraj et al. 2014). Generally, GSTs play vital roles in the detoxification and immune system of aquatic animals, and many studies have undertaken biochemical characterization and transcription profiles of GSTs after pathogenic and toxic chemical exposures. However, there is minimal information regarding the molecular structure of GSTs and their response to AFB1 from the black tiger shrimp.

The black tiger shrimp $P$. monodon is a major globally farmed species that requires a diet high in protein. Due to the high cost of fishmeal and environmental conservation concerns, people are seeking vegetable origin feedstuffs to replace fishmeal used in aqua feeds; however, feed with high concentration of plant ingredients, such as peanut, corn, soybean and rice bran are more susceptible to mycotoxin contamination (Zychowski et al. 2013). Mycotoxins are toxic metabolites produced naturally by certain fungal species that represent an unavoidable problem due to their presence in globally consumed cereals (Marroquín-Cardona et al. 2014; da Rocha et al. 2014). Among all of known mycotoxins, aflatoxins are the most investigated and are classified as group I carcinogen by International Agency for Research on Cancer (IARC, 1994). Four major aflatoxins (AFB1, AFB2, AFG1 and AFG2) have been reported as direct contaminants in feed ingredients and formulated diets (Raghavan et al. 2011). It was reported that AFB1 caused abnormalities such as poor growth, low apparent digestibility, physiological disorder and histological changes principally in the hepatopancreas of L. vannamei (Ostrowski-Meissner et al. 1995; Tapia-Salazar et al. 2012) and P. monodon (Boonyaratpalin et al. 2001; Gopinath and Raj 2009; Gopinath et al. 2012). However, the underlying metabolism and detoxification mechanisms of AFB1 in P. monodon warrants further investigation.

Previous studies have demonstrated that GSTs play a crucial role in the detoxification of AFB1 by catalyzing the conjugate formation of exo-AFB1-8,9-epoxide-GSH (AFBOGSH) (Rawal et al. 2010) and are considered a major factor in the determination of species sensitivity to AFB1 (Hayes et al. 1991; Dohnal et al. 2014; Tulayakul et al. 2005). To elucidate the function of GSTs and their roles in the defense mechanisms of $P$. monodon against AFB1, the aims of this study were to clone and characterize a Mu-class GST 
cDNA from $P$. monodon and to investigate the mRNA and protein accumulation after $P$. monodon exposure to AFB1 within 8 weeks.

\section{Methods}

\section{Diet preparation and dietary treatments}

Six experimental diets containing 0 (D0), 50 (D1), 100 (D2), 500 (D3), 1000 (D4), and 2500 (D5) $\mu \mathrm{g} / \mathrm{kg}$ AFB1 (Sigma Chemicals, St. Louis, MO, USA) were used to assess the toxic effects of AFB1 on black tiger shrimp P. monodon. The formulation and approximate composition of the six experimental diets were shown in Table 1. The diets were prepared according to the method described by Niu et al. (2008). All ingredients were ground in a laboratory grinder and sifted using a $60 \mu \mathrm{m}$ sieve. Raw material of each of

Table 1 Ingredients and nutrient composition of the basal diet (g/100 g dry matter)

\begin{tabular}{|c|c|c|c|c|c|c|}
\hline Ingredient & & & & & & $\%$ \\
\hline White fish meal ${ }^{a}$ & & & & & & 31 \\
\hline Soybean meal ${ }^{b}$ & & & & & & 16.3 \\
\hline Peanut bran ${ }^{b}$ & & & & & & 17 \\
\hline Wheat flour ${ }^{b}$ & & & & & & 19 \\
\hline Beer yeast $^{b}$ & & & & & & 5 \\
\hline Squid meal ${ }^{b}$ & & & & & & 3 \\
\hline Soybean lecithin ${ }^{c}$ & & & & & & 2 \\
\hline Fish oil $^{d}$ & & & & & & 1 \\
\hline Soybean oil ${ }^{\mathrm{a}}$ & & & & & & 1 \\
\hline Choline chloride (50 \%) & & & & & & 0.6 \\
\hline Monocalcium phosphate & & & & & & 1 \\
\hline Ascorbic phosphate ester ${ }^{\mathrm{e}}$ & & & & & & 0.1 \\
\hline Vitamin premix ${ }^{\mathrm{f}}$ & & & & & & 1 \\
\hline Mineral premix ${ }^{9}$ & & & & & & 1 \\
\hline Sodium alginate & & & & & & 1 \\
\hline \multicolumn{7}{|c|}{ Proximate composition of each $\operatorname{diet}^{\mathrm{h}}(\mathrm{g} / \mathrm{kg})$} \\
\hline Groupi & D0 & D1 & D2 & D3 & D4 & D5 \\
\hline Aflatoxin $B 1^{j}(\mu \mathrm{g} / \mathrm{kg})$ & 0 & 50 & 100 & 500 & 1000 & 2500 \\
\hline Crude protein & 47.31 & 47.26 & 47.35 & 47.61 & 47.44 & 47.56 \\
\hline Lipid & 8.93 & 7.79 & 8.41 & 8.27 & 8.01 & 8.65 \\
\hline Ash & 11.46 & 11.43 & 11.66 & 11.64 & 11.7 & 11.83 \\
\hline Moisture & 9.65 & 9.80 & 9.75 & 9.71 & 9.75 & 9.61 \\
\hline
\end{tabular}

${ }^{a}$ Imported from N.E.L.T.O. Australia Pty Ltd

b Zhuhai Shihai Feed Corporation Ltd, Zhuhai, China

c Kemin Industries (Zhuhai) Ltd., Zhuhai, China

d Imported from New Zealand (Bakels Edible Oils Ltd, Mt Macnganui)

e Guangzhou Chengyi Company Ltd., Guangzhou, China

f Vitamin premix (g/kg): h-Carotene, 3 M.I.U.; Cholecalciferol, 0.6 M.I.U.; Thiamin, 3.6; Riboflavin, 7.2; Pyridoxine, 6.6; Cyanocobalamine, 0.02; a-Tocopherol, 16.5; Menadione, 2.4; Niacin, 14.4; Pantothenic acid, 4; Biotin, 0.02; Folic acid, 1.2; Inositol, 30; Ascorbic acid, 100; cellulose was used as a carrier

${ }_{9}$ Mineral premix (g/kg): $\mathrm{P}, 120 ; \mathrm{Ca}, 120 ; \mathrm{Mg}, 15 ; \mathrm{Fe}, 1.5 ; \mathrm{Zn}, 4.2 ; \mathrm{Cu}, 2.1 ; \mathrm{K}, 75 ; \mathrm{Co}, 0.11 ; \mathrm{Mn}, 1.6 ; \mathrm{Se}, 0.01 ; \mathrm{Mo}, 0.005 ; \mathrm{Al}, 0.025 ; \mathrm{I}$, 0.4 ; cellulose was used as a carrier

${ }^{\mathrm{h}}$ Measured values

i Group: D0, $0 \mu \mathrm{g} / \mathrm{kg}$ AFB1; D1, $50 \mu \mathrm{g} / \mathrm{kg}$ AFB1; D2, $100 \mu \mathrm{g} / \mathrm{kg}$ AFB1; D3, $500 \mu \mathrm{g} / \mathrm{kg}$ AFB1; D4, $1000 \mu \mathrm{g} / \mathrm{kg}$ AFB1; D5, $2500 \mu \mathrm{g} /$ $\mathrm{kg}$ AFB1

j Aflatoxin $B_{1}$ was purchased from Sigma (St. Louis, MO, USA) 
the components of the experimental diets were weighed, combined and thoroughly mixed to homogeneity in a Hobart-type mixer. Next, oil was added and thoroughly mixed for 5 min. Deionized water (30\% of the dry ingredient mixture) was added and mixed until the consistency was suitable for pelleting. The wet mixture was extruded in a monoscrew extruder (Institute of Chemical Engineering, South China University of Technology, Guangzhou, China) through a $1.0 \mathrm{~mm}$ die. The resulting pellets were steamed in an electric oven at $90{ }^{\circ} \mathrm{C}$ for $40 \mathrm{~min}$ for starch gelatinization and then dried at $25^{\circ} \mathrm{C}$ with the aid of an air conditioner and an electrical fan. All of the resulting diet was stored at $-20^{\circ} \mathrm{C}$ until feeding.

\section{Experimental animals and culture}

Shrimp were obtained from a semi-intensive culture pond at Shenzhen Base, South China Sea Fisheries Research Institute of Chinese Academy of Fishery Sciences (Shenzhen, Guangdong), and all shrimp were fed with the basal diet (D0) for one week to acclimate to the experimental diets and conditions. A total of 540 healthy shrimp with an initial body weight of $1.15 \pm 0.02 \mathrm{~g}$ were randomly allocated to 18 fiberglass tanks (800 L, $0.5 \mathrm{~m}^{2}$ bottom areas, 30 shrimp per tank), with three tanks total being fed with each one of the six diets. Each tank contained $600 \mathrm{~L}$ of sand-filtered seawater and was covered with a plastic mesh lid to prevent the shrimp from jumping out. The water was continuously aerated with two air stones. During the feeding trial, the range of water salinity and temperature was $37-38 \mathrm{~g} / \mathrm{L}$ and $28-30{ }^{\circ} \mathrm{C}$, respectively. All shrimp in each tank were initially fed daily with $6 \%$ of their total body weight and were hand-fed to apparent satiation three times daily (8:00, 17:00 and 22:00). During the feeding trial, the amount of diet administered was progressively altered and adjusted according to the appetite of the shrimp by checking the excess feed at the bottom of the tanks after feeding for $1 \mathrm{~h}$. Thus, overfeeding was minimized, and shrimp were fed close to satiation. The feeding trial lasted for 56 days.

\section{Sample collection and preservation}

Hepatopancreas and muscle tissue of three shrimp from each tank were randomly sampled at 14, 28, 42 and 56 days and were immediately divided into two parts to quantify $P m M u G S T$ mRNA and analyze PmMuGST protein accumulation. All samples were stored in liquid nitrogen. At the end of the feeding trial, shrimp were fasted for $24 \mathrm{~h}$ and then weighed to measure growth performance. The growth performance and survival of P. monodon of all groups were calculated using the following equations:

Weight gain $(\mathrm{WG}, \%)=($ mean final body weight - mean initial body weight $) /$ mean initial body weight $\times 100$

Survival $(\%)=$ final number of shrimp/initial number of shrimp $\times 100$

\section{RNA isolation and CDNA synthesis}

Total RNA was extracted from the hepatopancreas and muscle tissues using TRIzol reagent (Invitrogen, Carlsbad, CA, USA) according to the manufacturer's protocol. DNA contamination was removed from the RNA using RQ1 RNase-Free DNase (Promega, 
Medisen, WI, USA). Hepatopancreas and muscle RNA was used as the template for first-strand cDNA synthesis using M-MLV reverse transcriptase (Promega, Medisen, WI, USA) following the manufacturer's instruction.

\section{PCR and cloning of PmMuGST CDNA}

Full-length $P m M u G S T$ cDNA was obtained using reverse-transcription polymerase chain reaction (RT-PCR), and the $3^{\prime}, 5^{\prime}$ rapid amplification of cDNA ends (RACE) method. Two pairs of degenerate primers (Table 2) were designed to clone a partial sequence of PmMuGST, based on the highly conserved nucleotide sequence of $\mathrm{Mu}$ class GST from L. vannamei (GenBank accession no. AY573381), F. chinensis (Ren et al. 2009b) and Rattus norvegicus (GenBank accession no. NM_017014). PCR amplification was performed using the cDNA template from the hepatopancreas. The first RT-PCRs were conducted as follows: $5 \mathrm{~min}$ at $94{ }^{\circ} \mathrm{C}$ for one cycle followed by another 30 cycles of $30 \mathrm{~s}$ at $94{ }^{\circ} \mathrm{C}, 30 \mathrm{~s}$ at $60{ }^{\circ} \mathrm{C}, 30 \mathrm{~s}$ at $72{ }^{\circ} \mathrm{C}$, and a final extension for $10 \mathrm{~min}$ at $72{ }^{\circ} \mathrm{C}$ followed by cooling to $4{ }^{\circ} \mathrm{C}$. The second nested RT-PCR program was consisted of one cycle of $94{ }^{\circ} \mathrm{C}$ for $5 \mathrm{~min}$, and another 30 cycles of $94{ }^{\circ} \mathrm{C}$ for $30 \mathrm{~s}, 55^{\circ} \mathrm{C}$ for $1 \mathrm{~min}, 72^{\circ} \mathrm{C}$ for 1 min followed by a 10 min extension at $72{ }^{\circ} \mathrm{C}$. A partial PmMuGST cDNA fragment of $172 \mathrm{bp}$ was obtained from two pairs of degenerate primers.

Based on the partial sequence data of PmMuGST, the $3^{\prime}$ and $5^{\prime}$ ends were obtained using a SMART ${ }^{\mathrm{TM}}$ RACE cDNA Amplification Kit (Clontech, Otsu, Shiga, Japan). The primers used for cloning the full-length cDNAs of $P m M u G S T$ are listed in Table 2. For the first $3^{\prime}$ RACE, the PCR was performed as follows: one cycle of $94{ }^{\circ} \mathrm{C}$ for $3 \mathrm{~min} ; 5$ cycles of $94{ }^{\circ} \mathrm{C}$ for $30 \mathrm{~s}, 72{ }^{\circ} \mathrm{C}$ for $3 \mathrm{~min} ; 5$ cycles of $94{ }^{\circ} \mathrm{C}$ for $30 \mathrm{~s}, 70{ }^{\circ} \mathrm{C}$ for $30 \mathrm{~s}$, and $72{ }^{\circ} \mathrm{C}$ for $3 \mathrm{~min}$; 25 cycles of $94{ }^{\circ} \mathrm{C}$ for $30 \mathrm{~s}, 68^{\circ} \mathrm{C}$ for $30 \mathrm{~s}, 72{ }^{\circ} \mathrm{C}$ for $3 \mathrm{~min}$; and finally cooled to $4{ }^{\circ} \mathrm{C}$. For the second $3^{\prime}$ end RACE, the reaction was carried out with UPM and a $3^{\prime}$ nested PCR primer (Table 2) using the first PCR product under the following conditions: one cycle of $94{ }^{\circ} \mathrm{C}$ for $3 \mathrm{~min} ; 25$ cycles of $94{ }^{\circ} \mathrm{C}$ for $30 \mathrm{~s}, 68{ }^{\circ} \mathrm{C}$ for $30 \mathrm{~s}, 72{ }^{\circ} \mathrm{C}$

Table 2 Oligonucleotide primers used in this study

\begin{tabular}{lll}
\hline Primers & Sequences $\left(\mathbf{5}^{\prime} \mathbf{- 3}^{\prime} \mathbf{)}\right.$ & Sequence information \\
\hline MuGST-F1 & CCTACGAGATCTTCGACCAGCACCT & Degenerate primers \\
MuGST-R1 & CYYCTYCAYTTCRTATYTCTTCCTCT & Degenerate primers \\
MuGST-F2 & CAGGCTTTCCAGAAGAGGTTTG & Nested degenerate primers \\
MuGST-R2 & GATCGTAAACTGAGCGTACTTGTTGC & Nested degenerate primers \\
PmMuGST-F1 & CAGGAAGTACATGGCGTCCCCGGATTTC & 3' RACE PCR \\
PmMuGST-F2 & GTAGATGGCTTGGTTTATGAAGAGGAAGA & 3' RACE-nested PCR \\
PmMuGST-R1 & TTCTTCCTCTTCATAAACCAAGCCATCTAC & 5' RACE PCR \\
PmMuGST-R2 & CCTGATGAAATCCGGGGACGCCATGTAC & 5' RACE-nested PCR \\
EF1A-F & AGTATGCTCCTTTTGGACGTTTTGC & Real-time PCR \\
EF1A-R & CCTTTTCTGCGGCCTTGGTAGTC & Real-time PCR \\
PmMuGST-F & ACGGGCACTGAGTACGAGGAGAAG & Real-time PCR \\
PmMuGST-R & GGCAGATTTGGGAAGCGAGG & Real-time PCR \\
MuGST-EF & CGGGATCCATGGTGCCTGTCCTGGG & Recombinant expression \\
MuGST-ER & CCCAAGCTTTCATTTTCCCTCAGCGATC & Recombinant expression \\
\hline
\end{tabular}

$F$ and $R$ stand for forward primers and reverse ones, respectively. MUGST-EF and MUGST-ER containing flanking noncomplementary sequences (bold type) and the restriction sites (underlined). $\mathrm{Y}=\mathrm{C}$ or $\mathrm{T}, \mathrm{R}=\mathrm{A}$ or $\mathrm{G}$ 
for $3 \mathrm{~min}$. The gene-specific primer PmMuGST-R1 (Table 2) and UPM were applied to perform the first $5^{\prime}$ RACE, which PCR conditions were the same as that used for the first $3^{\prime}$ RACE. The second 5' RACE condition using the gene-specific primer PmMuGST-R2 and nested UPM, which PCR conditions were the same as that of the second $3^{\prime}$ RACE.

The amplified PCR products were resolved in a $2.0 \%$ agarose gel and the target PCR fragment was purified using the Wizard SV Gel and PCR clean-up System (Promega, Madisen, WI, USA). The purified fragments were then ligated into the pMD18-T vector (TaKaRa, Otsu, Shiga, Japan) and used to transform Escherichia coli cells. The recombinant bacteria were identified by blue/white screening method and confirmed by PCR. Plasmids containing the insert were purified by Pure Yield ${ }^{\mathrm{TM}}$ Plasmid Midiprep System (Promega, Madisen, WI, USA) and used as the template for DNA sequencing.

\section{Analysis of nucleotide and amino acid sequences}

The nucleotides and deduced amino acid sequences of PmMuGST cDNA were analyzed and compared using the BLAST search programs (NCBI, http://www.ncbi.nlm.nih.gov/ BLAST/). The signal peptide was predicted by SignalP program (http://www.cbs.dtu.dk/ services/SignalP/). The element of secondary structure of the deduced peptide from the clones was predicted by GOR4 software on the website (http://www.expasy.org/). The multiple sequence alignment of $P m M u G S T$ amino acid sequence was performed using the programs of Vector NTI advance 10.3 (Invitrogen). The CD-Search service was used to identify the conserved domains (CDs) present in predicted protein sequences against NCBI's Conserved Domain Database (CDD, http://www.ncbi.nlm.nih.gov/Structure/ cdd/cdd.shtml.) Phylogenetic tree and molecular evolutionary analysis were conducted using MEGA version 6 (Tamura et al. 2013).

\section{Tissue distribution of PmMuGST mRNA}

To investigate the basal (control) mRNA level of PmMuGST in various tissues, total RNA was extracted from eight tissues, including hemocytes, hepatopancreas, muscle, heart, ovary, stomach, eyestalk and intestine, from three healthy $P$. monodon using Trizol regent (Invitrogen, UAS). The amount of PmMuGST mRNA in the different tissues was determined by quantitative real-time PCR (RT-PCR). The RNA samples were analyzed in $1.0 \%$ agarose electrophoresis and quantitated at $260 \mathrm{~nm}$, and all $\mathrm{OD}_{260} / \mathrm{OD}_{280}$ ratios were between 1.8 and 2.0. Total RNA $(1 \mu \mathrm{g})$ was reverse transcribed using the PrimeScript $^{\text {TM }}$ Real time PCR Kit (TaKaRa, Otsu, Shiga, Japan) for real-time quantitative RTPCR analysis. Elongation factor 1-alpha (EF1A) of P. monodon (GenBank accession no. GU136229) was used as an internal control.

\section{Recombinant expression of PmMuGST in E. coli}

The primers for MuGST-EF and MuGST-ER (Table 2) contain flanking non-complementary sequences (bold type) so that the desired restriction sites (underlined) are included in the amplicons. The primers were added to the PCR reaction mix to amplify the MuGST cDNA fragments, which encoded the mature MuGST protein. PCR reactions of $10 \mu \mathrm{L}$ consisted of $2 \mu \mathrm{L}$ cDNA template, $0.4 \mu \mathrm{L}$ each of $10 \mu \mathrm{M}$ forward and reverse primer, $1 \mu \mathrm{L} 10 \times$ PCR Buffer, $1 \mu \mathrm{L} 2.5 \mathrm{mM}$ dNTPs, $0.5 \mu \mathrm{L}$ Taq DNA polymerase (5 U/ $\mu \mathrm{L}$ ) LA and $4.7 \mu \mathrm{L}$ PCR-grade $\mathrm{H}_{2} \mathrm{O}$. The mixture was denatured at $95^{\circ} \mathrm{C}$ for $3 \mathrm{~min}$ 
followed by 35 cycles of $95{ }^{\circ} \mathrm{C}$ for $30 \mathrm{~s}, 60{ }^{\circ} \mathrm{C}$ for $30 \mathrm{~s}$ and $72{ }^{\circ} \mathrm{C}$ for $1 \mathrm{~min}$. The resulting PCR products (660 bp) containing the complete MuGST cDNA were digested with BamHI-HindIII restriction enzymes and then cloned into the pET28a(+) vector (Novagen, Darmstadt, Germany). Prior to cloning, the vector was also digested with BamHIHindIII enzymes. Thus, a coding region for the N-terminal $\mathrm{His}_{6}$ tag was fused to the MuGST open reading frame. The correct sequence and in-frame insertion location of the insert were verified by DNA sequencing. The recombinant plasmids used to transform E. coli BL21 (DE3) (MerckMillipore, USA) and then induced with IPTG following the previously reported method (Wang et al. 2011). Finally, the synthesis of the recombinant protein was demonstrated by SDS-PAGE (12\% separating gel and $5 \%$ stacking gel).

\section{Recombinant protein purification, polyclonal antibody preparation and western blot analysis}

The culture volume was increased to $300 \mathrm{~mL}$ to obtain more recombinant protein. The transformed E. coli was incubated at $37^{\circ} \mathrm{C}$ for $4 \mathrm{~h}$ at $200 \mathrm{rpm}$ after inducing with $1 \mathrm{mM}$ IPTG. The E. coli cells were harvested by centrifugation at $4{ }^{\circ} \mathrm{C}$, and washed with icecold phosphate-buffer saline (PBS, $\mathrm{pH}$ 7.4) for three times, and then were sonicated for 30 min discontinuously (stopped from $10 \mathrm{~s}$ to $10 \mathrm{~s}$ to allow cooling of the sample) at $100 \mathrm{~W}$ on ice. After centrifugation $(\times 10,000 \mathrm{~g})$ at $4{ }^{\circ} \mathrm{C}$ for $30 \mathrm{~min}$, the supernatant was used for the purification of the recombinant protein through metal affinity chromatography (TALON Resin, Clontech TALON ${ }^{\circledR}$ Superflow ${ }^{\text {TM }}$ Metal Affinity Resin).

A polyclonal antiserum against PmMuGST was subsequently obtained from rabbits by injecting $1 \mathrm{mg}$ of the purified recombinant protein with complete Freund's adjuvant once and incomplete Freund's adjuvant (Sigma) at a 1-week interval (Nadala and Loh 1998; Sahul Hameed et al. 1998). The rabbits were injected four times. The antiserum was collected from the rabbits at the end of the week after the last boost. Cell free protein extract from transformed bacteria was resolved in SDS-PAGE (12\% separating gel and $5 \%$ stacking gel) and transferred to Immobilon membranes (MerckMillipore, USA). A protein that reacted with an anti-PmMuGST antibody (1:1000) and a horseradish peroxidase-conjugated goat anti-rabbit IgGs secondary antibody (1:2500) (Pierce, Thermo Fisher Scientific, Rockford, USA) was detected in the western blot analysis.

\section{Quantification of PmMuGST mRNA by real-time PCR}

The mRNA level of PmMuGST in the hepatopancreas and muscle of P. monodon in response to AFB1 exposure were analyzed using a quantitative real-time PCR method, as previously described (Livak and Schmittgen 2001; Bergallo et al. 2010) (ABI StepOne Plus, Applied Biosystems, Foster City, CA, USA). A pair of gene-specific primers (PmMuGST-F and PmMuGST-R) was designed to amplify a product with $133 \mathrm{bp}$. A pair of primers of EF1A-F and EF1A-R (Table 2) was used to amplify a 120 bp length of fragment of EF1A mRNA as an internal control to verify the successful reverse transcription and to calibrate the cDNA template. Nuclease-Free water was used in the place of cDNA templates as a negative control. All samples were repeated in triplicate $(n=3)$. The qRTPCR amplifications were carried out in a total reaction volume of $20 \mu \mathrm{L}$ containing $10 \mu \mathrm{L}$ $2 \times$ Master Mix (Fermentas K0223, Thermo Fisher Scientific, Ottawa, ON, Canada), $0.8 \mu \mathrm{L}$ cDNA, $0.3 \mu \mathrm{L}$ each of $10 \mu \mathrm{M}$ forward and reverse primer and $8.6 \mu \mathrm{L}$ pcr-grade 
water. The real-time PCR program consisted of $95^{\circ} \mathrm{C}$ for $10 \mathrm{~min}$, followed by 40 cycles of $95{ }^{\circ} \mathrm{C}$ for $15 \mathrm{~s}, 60^{\circ} \mathrm{C}$ for $30 \mathrm{~s}$, and $72{ }^{\circ} \mathrm{C}$ for $15 \mathrm{~s}$. Melting curve analysis of the amplified products was performed at the end of each reaction to confirm that only one PCR product was amplified and detected. The fluorescent real-time PCR data were analyzed using 7500 System SDS Software (Applied Biosystems, Foster City, CA, USA).

\section{Analysis of PmMuGST protein in the hepatopancreas by western blotting after AFB1 exposure}

Hepatopancreas tissues of three P. monodon from each tank were collected at 14, 28, 42, and 56 days and were ground in liquid nitrogen, and RIPA lysis buffer (Boyotime, China) was added. The homogenates were centrifuged $(12,000 \mathrm{~g}, 30 \mathrm{~min})$ at $4{ }^{\circ} \mathrm{C}$ to collect the supernatants. Total protein concentrations in each shrimp tissue extract were determined using a Thermo $\mathrm{BCA}^{\mathrm{TM}}$ protein assay kit. Equal amount of protein $(30 \mu \mathrm{g})$ was added per lane of the gel for SDS-PAGE and western blotting analysis. The protein extracts were separated by $12 \%$ SDS-PAGE and transferred onto PVDF membranes (MerckMillipore, USA). The membranes were blocked for $2 \mathrm{~h}$ at room temperature in the Blocking solution ( $5 \% \mathrm{w} / \mathrm{v}$ skim milk, $1 \times \mathrm{TBS}, 0.1 \%$ Tween-20), and then treated with anti-PmMuGST antibodies diluted in the Blocking solution $(1: 300)$ at $4{ }^{\circ} \mathrm{C}$ with gentle shaking overnight. After washing in TBS $(24.23 \mathrm{~g} / \mathrm{L}$ Tris- $\mathrm{HCl}, 80.06 \mathrm{~g} / \mathrm{L} \mathrm{NaCl}, \mathrm{pH}$ 7.6) for three times, the membranes were incubated for $1 \mathrm{~h}$ at room temperature with horseradish peroxidase-conjugated goat anti-rabbit IgGs secondary antibody (1:1000) (Pierce, Thermo Fisher Scientific, Rockford, USA). Enhanced chemiluminescence substrates (Pierce, Thermo Fisher Scientific, Rockford, USA) were subsequently added to the membranes for $5 \mathrm{~min}$. Each membrane was exposed to X-ray film (Uvipro) after removing the substrates according to the manufacturer's instruction. Films were exposed to the membranes from 1 to $30 \mathrm{~s}$ initially and then adjusted exposure time depending on the signal intensity. After the exposure, X-ray films were removed from X-ray holder and quickly immersed into the developer. When the bands appeared, the development was immediate terminated. And the films were immersed in the fixer until were transparent. The films dried at room temperature. The optical density of the bands was determined directly on the film using IPP6.0 Analysis software. The relative intensity of objective protein was calculated based on the optical density ratio of PmMuGST and GAPDH band. GAPDH protein was used as an internal control. The amounts of GAPDH were also assessed to monitor the equal loadings of protein extracts.

\section{Statistical analysis}

Data were expressed as the mean \pm standard deviation (SD) unless otherwise indicated. The significant differences between groups were analyzed using one-way ANOVA. If significant differences were indicated at the 0.05 level, then Duncan's Multiple Range comparison tests were applied to identify significant differences among treatments. The linear relationships among PmMuGST (relative PmMuGST mRNA expression levels and relative PmMuGST protein levels), AFB1 concentrations and times were tested using the General Linear Models procedure (GLM) of SPSS 16.0. Differences were considered to be significant at $P<0.05$. 


\section{Results}

\section{Growth performance and survival of $P$. monodon}

Shrimp fed with diets containing AFB1 $(50-100 \mu \mathrm{g} / \mathrm{kg})$ had lower WG as than D0 group (control), but there were no significant differences $(P>0.05)$. Moreover, shrimp fed with diets containing AFB1 (500-2500 $\mu \mathrm{g} / \mathrm{kg}$ ) exhibited significantly lower WG compared with the control group $(P<0.05)$. There were no significant differences in shrimp survival among all groups after feeding for 56 days (Table 3 ).

\section{Analysis of the PmMuGST sequence and the predicted protein}

The full-length 867 bp PmMuGST cDNA of P. monodon (GenBank accession number KM023785) includes an open reading frame of 660 bp encoding 219 amino acid residues, a $3^{\prime}$ non-coding region of 173 bp with a polyadenylation signal (AATAAA) and a poly(A) tail (Fig. 1). Signal $P$ analysis did not predict any signal peptide sequence in PmMuGST. The calculated molecular mass and $\mathrm{p} I$ were $25.61 \mathrm{kDa}$ and 6.15 , respectively. The full-length cDNA sequence of PmMuGST was first reported in this study and showed similarity to the GST sequence of L. vannamei. The predicted amino acid sequence of PmMuGST was found to be similar to the proteins of GST class Mu when analyzed by BLASTp with a creditable expectation value (E value $\leq 10^{-3}$ ). In a search of the CDs using the CD-Search service against NCBI's CDD, the predicted protein sequence of PmMuGST cDNA was matched to CDs of the GST_N_Mu_like (PSSM: cd03075) and GST_C_family_superfamily_like (PSSM: cl02776) (Fig. 1). Additionally, the predicted protein sequence of PmMuGST cDNA also contains a G-site (from Pro $^{3}$ to $\mathrm{His}^{84}$ ) that binds the GSH in the $\mathrm{N}$-terminal region and an $\mathrm{H}$-site (from $\mathrm{Glu}^{92}$ to $\mathrm{Tyr}^{210}$ ) that is a substrate binding site in the C-terminal (Fig. 1). In the GST_N_ $\mathrm{Mu}$ _like domain, the secondary structural elements were arranged in a $\beta \alpha \beta \alpha \beta \beta \alpha$ conformation. Similar to other Mu-class GSTs, the PmMuGST amino acid sequence also possessed a $\mathrm{Mu}$ loop between $\beta 2$ and $\alpha 2$. The position of the seven amino acid $\mathrm{Mu}$ loop was located at residues 36-42 (GDAPAYD), which was shorter compared to those of mammals (Fig. 1).GST_C_family_superfamily_like domain consisted of four long and one short $\alpha$ helices and a short $\beta$ sheet. The major stabilization factor in the G-site of Mu class GSTs is Tyr7 (Y) (Blanchette et al. 2007), which was also found in the sequence of PmMuGST (Fig. 1). As in the other GSTs, PmMuGST contains the conserved G-site motif FPNLPYYIDGD between the residue 57 and 67 (ContrerasVergara et al. 2004).

Table 3 Growth performance of $P$. monodon after dietary AFB1 stress for 56 days $(n=3)$

\begin{tabular}{llllccl}
\hline Group & D0 & D1 & D2 & D3 & D4 & D5 \\
\hline WG & $320.18 \pm 28.22^{c}$ & $293.76 \pm 10.27^{\mathrm{bc}}$ & $287.23 \pm 25.04^{\mathrm{bc}}$ & $272.37 \pm 13.64^{\mathrm{b}}$ & $265.45 \pm 25.35^{\mathrm{b}}$ & $90.46 \pm 13.14^{\mathrm{a}}$ \\
Survival & $73.33 \pm 6.67$ & $72.22 \pm 3.85$ & $75.56 \pm 1.93$ & $72.22 \pm 9.62$ & $65.56 \pm 1.93$ & $66.67 \pm 6.67$ \\
\hline
\end{tabular}

Values are expressed as the mean \pm SE of three replicates. The different lowercase letters represented the significant difference in the different group $(P<0.05)$

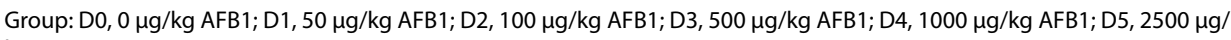
kg AFB1

Weight gain $(\mathrm{WG}, \%)=($ mean final body weight - mean initial body weight $) /$ mean initial body weight $\times 100$

Survival $(\%)=$ final number of shrimp/initial number of shrimp $\times 100$ 


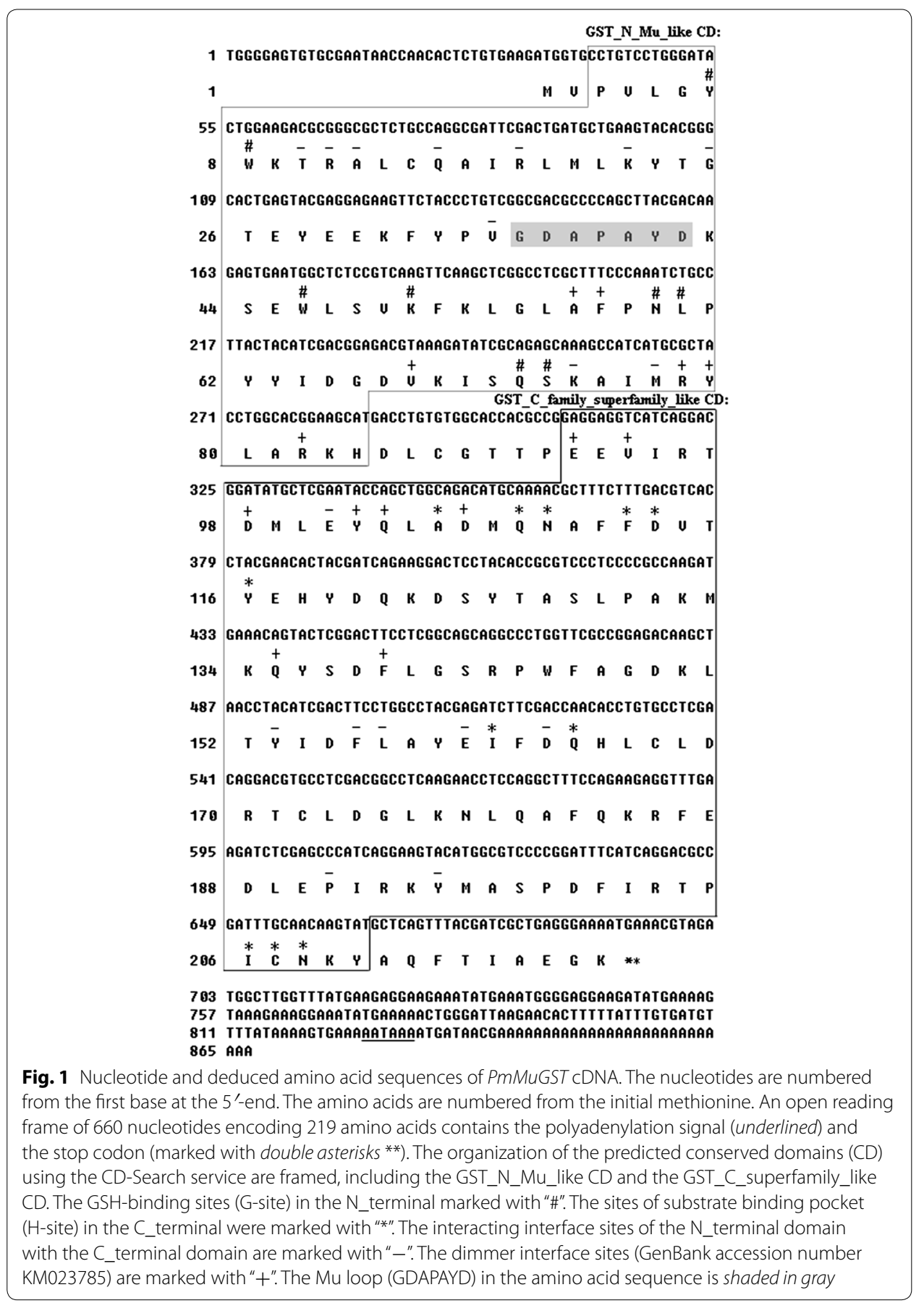

\section{Homology analysis}

A BLSATP search revealed that the PmMuGST amino acid sequence had an overall similarity of $42-86 \%$ with Mu class GSTs of other species (Table 4). PmMuGST exhibited the highest similarity (86 \%) with an L. vannamei GST and the lowest similarity with a Mu class GST of Fasciola hepatica (Table 4).

Multiple alignment analysis of $P m M u G S T$ with other known GSTs revealed that the N-terminal region of all of the GSTs was highly similar and conserved, while the 
Table 4 Comparison of predicted PmMuGST amino acid with mu GST of other species

\begin{tabular}{lll}
\hline GenBank number & Species & Similarities (\%) \\
\hline AAT76663 & Litopenaeus vannamei & 86 \\
AGJ70295 & Macrobrachium nipponense GST & 57 \\
AFM86755 & Callorhinchus milii Mu3 GST & 56 \\
ACO14549 & Esox lucius Mu3 GST & 56 \\
NP_001103586 & Danio rerio GST & 55 \\
NP_058710 & Rattus norvegicus Mu1 GST & 55 \\
ABD67509 & Cyprinus carpio Mu GST & 55 \\
P15626 & Mus musculus Mu 2 GST & 53 \\
P46439 & Homo sapiens Mu5 GST & 51 \\
P20136 & Gallus gallus mu GST & 49 \\
P31670 & Fasciola hepatica mu GST & 42 \\
\hline
\end{tabular}

C-terminal was relatively diverse (Fig. 2). The numbers of consensus amino acid sequences that are shaded in black in the $\mathrm{N}$-terminal region (from 3 to $84 \mathrm{bp}$ ) are higher than those in the C-terminal region (from 92 to $210 \mathrm{bp}$ ). Each GST is known to contain a G-site that binds the GSH substrate in its N-terminal and an H-site that binds xenobiotic compounds in the C-terminal (Armstrong 1997). All of the members of the highly diverse GST super family are capable of binding the tripeptide GSH; thus, it has been suggested that the structural features of the G-site might share a highly conserved amino acid sequence (Ren et al. 2009a). The $\mathrm{H}$-site that binds xenobiotic compounds is the primary structure accounting for specificity and activity of GSTs, and it lacks amino acid sequence similarity to the G-site (Sheehan et al. 2001).

The phylogenetic tree was constructed using the neighbor-joining distance method in MEGA version 6.0. The known GSTs were classified into two groups (Fig. 3): one was GST class-Mu of crustaceans and the second one was GST class-Mu of mammalian and fish. The deduced amino acid of PmMuGST was in the same group as the GST from L. vannamei, Procambarus clarkii and M. nipponense. This group differed from the other groups containing the mammalian and the fish GST class-Mu subgroup, such as the mammalian GST class-Mu subgroup of $R$. norvegicus, Cricetulus longicaudatus, $M$. musculus, Sus scrofa, Bos taurus, H. sapiens and G. gallus, and the fish class-Mu subgroup of Oreochromis niloticus, D. rerio, C. carpio, E. lucius, Kryptolebias marmoratus and Anoplopoma fimbria. PmMuGST belongs to the crustacean GST class-Mu and was more closely related to the GST class-Mu of $L$. vannamei and P. clarkii than to that of $M$. nipponense. These results strongly support a common evolutionary lineage for shrimp GST class-Mu.

\section{Tissue distribution of PmMUGST mRNA}

The tissue-specific distribution of the basal (control) PmMuGST mRNA was determined by quantitative real-time RT-PCR. PmMuGST mRNA was found in all sampled tissues. As shown in Fig. 4, the maximum quantity of PmMuGST mRNA was found in the muscle, followed by the hepatopancreas, hemocytes, eyestalk, stomach, heart, intestine, and ovary. 


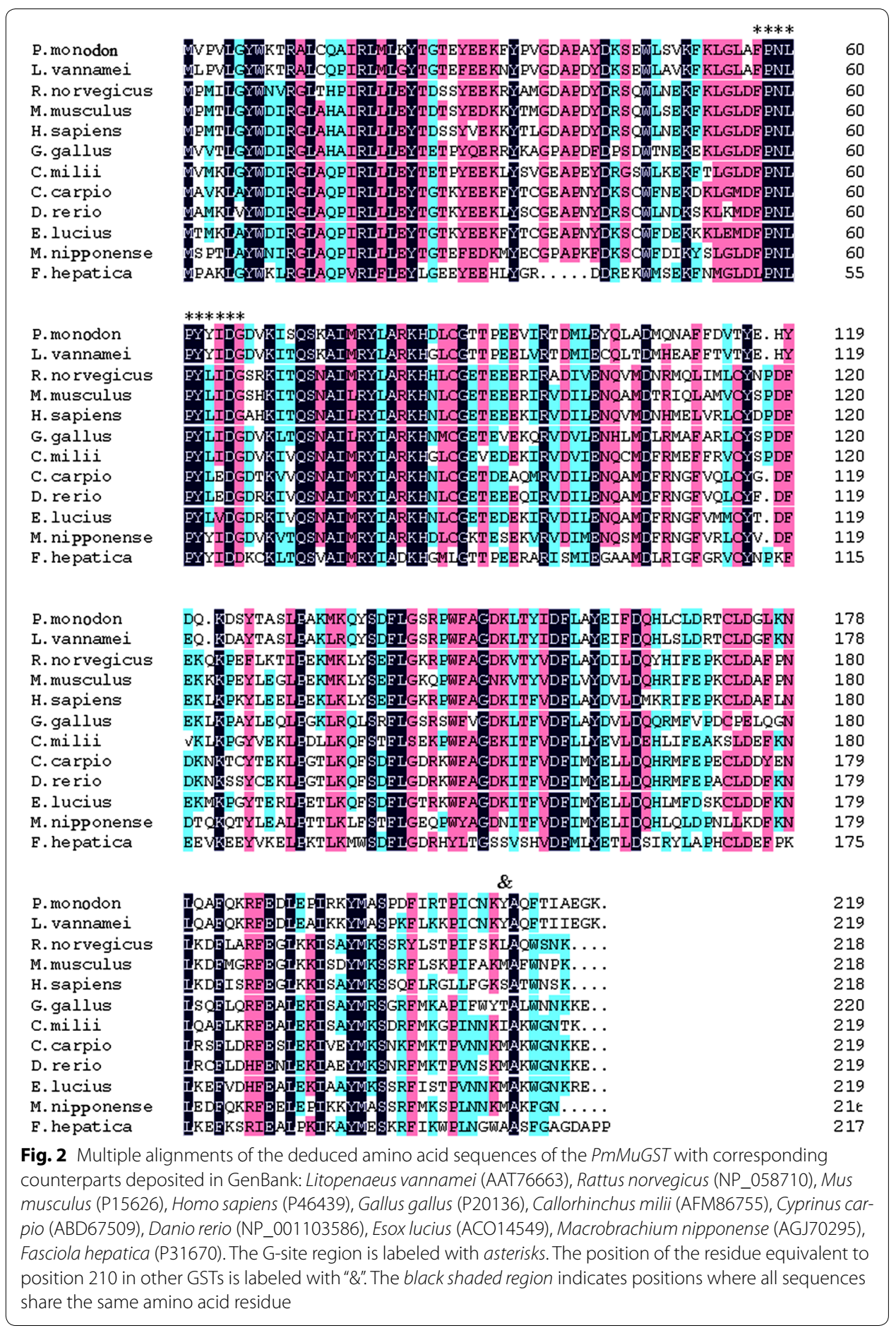

\section{Purification of the PmMuGST recombinant protein and western blot analysis}

The recombinant expression vector pET28a was transformed into the BL21 (DE3) strain and was over expressed as a His $_{6}$-tagged protein after IPTG induction for $4 \mathrm{~h}$. SDSPAGE analysis revealed that the PmMuGST recombinant protein was very prominent on the stained gel (Fig. 5a). The PmMuGST recombinant protein was purified using 

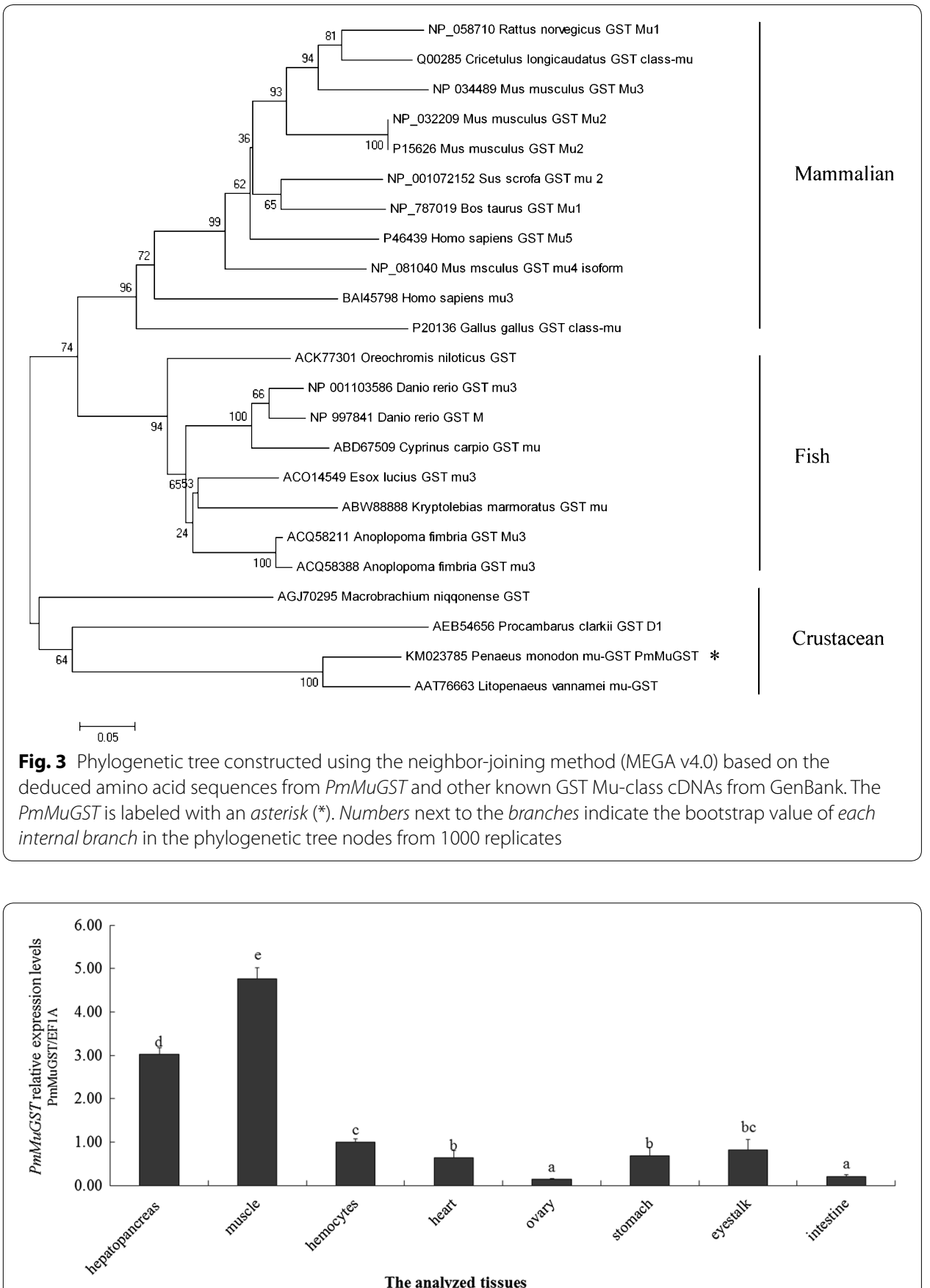

Fig. 4 Tissue distribution of PmMUGST mRNA in P. monodon. QRT-PCR was performed with RNA from the hepatopancreas, muscle, hemocytes, heart, ovary, stomach, eyestalk and intestine samples of three healthy shrimp. Each sample was run in triplicate. The elongation factor 1-alpha (EF1A) gene was used as an internal control to calibrate the cDNA template for all the samples using the method described in the previous papers. Vertical bars represent the mean \pm SD $(n=3)$. One-way ANOVA was used to compare different tissue distribution of expression levels. The different lowercase superscripts represent significant differences in pairwise comparisons with control group $(P<0.05)$

the metal affinity chromatography. The recombinant protein contained the amino acid of the expression plasmid pET28a (+), which included a His-tag (HHHHHH) and a T7-tag (MASMTGGQQ). The calculated molecular mass of recombinant protein was 
$29.02 \mathrm{kDa}$ and was larger than that of the mature PmMuGST (Fig. 5a). A band of approximately $35 \mathrm{kDa}$ in size corresponding to the His-tag PmMuGST recombinant protein was observed after IPTG induction and was found to react with the anti-PmMuGST antibody. No bands were found in the same position in the BL21 (DE3) without the plasmid (Fig. 5a). The recombinant protein PmMuGST was successfully recognized with a rabbit anti-PmMuGST antibody (Fig. 5b).

\section{Expression profiles of PmMuGST in the hepatopancreas and muscle of $P$. monodon after exposure to AFB1}

The transcript levels of $P m M u G S T$ in the hepatopancreas of shrimp decreased with the increase of AFB1 level $(0-2500 \mu \mathrm{g} / \mathrm{kg})$, while increased with the increased AFB1 exposure times (14-56 days) (Fig. 6a). Analysis of variance indicated there was significant interaction between the effect of AFB1 dose and exposure time on PmMuGST mRNA expression $(P<0.05)$ (Table 5). PmMuGST mRNA transcript levels in the hepatopancreas of D5 group were significantly lower than those of D0 group after exposure to AFB1 from 14 to 56 days. PmMuGST transcript levels of D4 group were significantly lower than that of D0 group at 14 and 56 days. The transcript levels of PmMuGST in the hepatopancreas of D3 group were significantly higher than that of D0 group at 28 and 42 days (Fig. 6a).
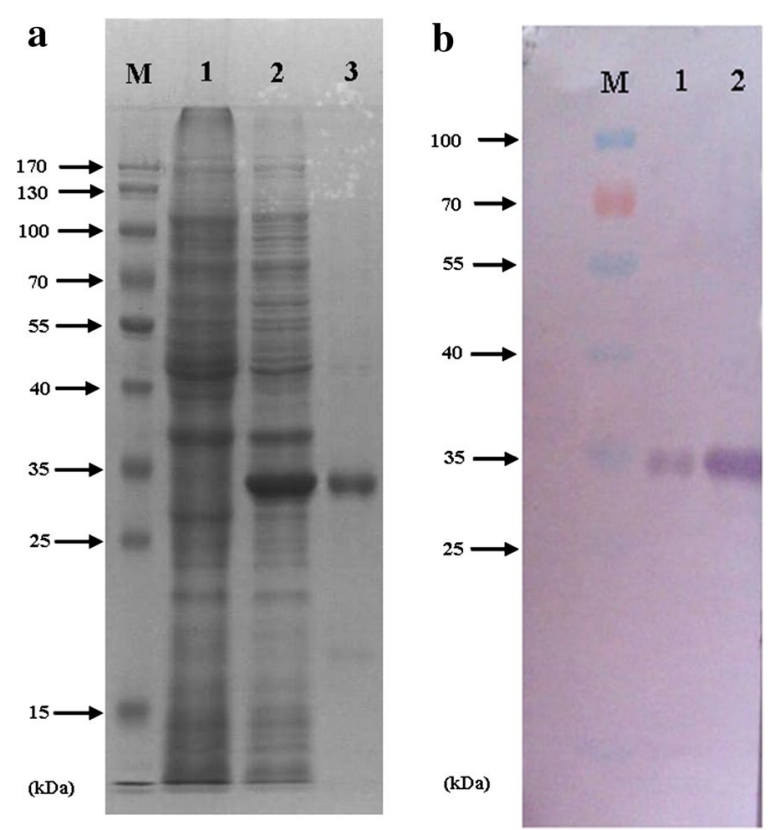

Fig. 5 Expression and purification of the recombination PmMuGST fusion protein. Equal amounts of proteins $(30 \mu \mathrm{g})$ were subject to SDS-PAGE and western blotting analysis. a Protein samples were separated by SDSPAGE and stained with Coomassie Brilliant Blue. Lane M, protein standard; lane 1, crude extract of BL 21 (DE3) without plasmid; lane 2, crude extract of the transformed BL21 (DE3) with recombined pET28a (+) plasmid induced with IPTG; lane 3, purified PmMUGST fusion protein. b Protein samples were analyzed by immunoblotting with anti-PmMUGST antibody. Lane M, protein standard; lane 1, crude extract of the transformed BL 21 (DE3) with recombined pET28a (+) plasmid induced with IPTG; lane 2, purified PMMUGST fusion protein 


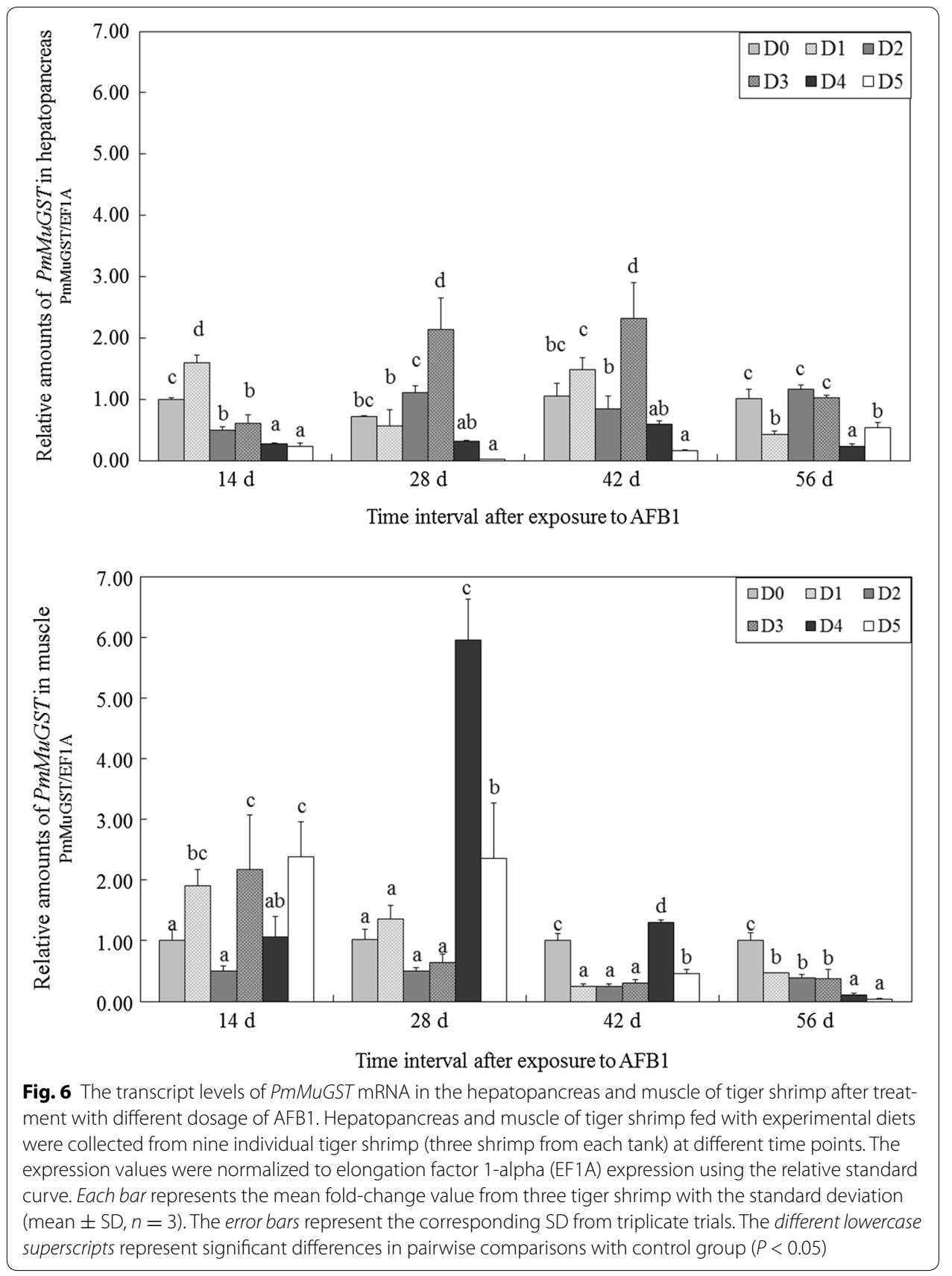

PmMuGST transcript levels in the muscle of shrimp increased with increase of AFB1 concentration ranging from 50 to $500 \mu \mathrm{g} / \mathrm{kg}$, and decreased with the increase of AFB1 concentration ranging from 500 to $2500 \mu \mathrm{g} / \mathrm{kg}$. The mRNA levels of $P m M u G S T$ in the muscle decreased with increased AFB1 exposure times in the range of 14 to 56 days (Fig. 6a). Analysis of variance indicated that there was significant interaction between the effects of AFB1 dose and exposure time on PmMuGST mRNA expression levels $(P<0.05)$ (Table 5). The transcript levels of $P m M u G S T$ in the muscle of D5 group were significantly higher than that of D0 group at 14 and 28 days. PmMuGST transcript levels in D4 group were significantly higher than that of D0 group at 28 and 42 days. At the end 
Table 5 ANOVA table of PmMuGST mRNA expression levels in the hepatopancreas and muscle and PmMuGST protein levels in the hepatopancreas of $P$. monodon after AFB1 exposure at 14, 28, 42 and $56 \mathrm{~d}$ (time, $\mathrm{T}$ ) at different AFB1 concentrations (A)

\begin{tabular}{lccccc}
\hline Source & $\mathbf{d f}$ & Sum of squares & Mean square & $\mathbf{F}$ & $\mathbf{P r} \boldsymbol{F}$ \\
\hline PmMuGST mRNA levels in the hepatopancreas (PmMuGST/EF1A) & & & \\
Corrected Model & 23 & 24.710 & 1.074 & 28.467 & 0.000 \\
$\mathrm{~A}$ & 5 & 13.350 & 2.670 & 70.751 & 0.000 \\
$\mathrm{~T}$ & 3 & 1.550 & 0.517 & 13.695 & 0.000 \\
$\mathrm{~A} \times \mathrm{T}$ & 15 & 9.809 & 0.654 & 17.327 & 0.000 \\
Error & 48 & 1.811 & 0.038 & & \\
Total & 72 & 75.711 & & & \\
PmMuGST mRNA levels in the muscle (PmMuGST/EF1A) & & & \\
Corrected Model & 23 & 107.151 & 4.659 & 39.906 & 0.000 \\
$\mathrm{~A}$ & 5 & 19.343 & 3.869 & 33.138 & 0.000 \\
T & 3 & 30.156 & 10.052 & 86.104 & 0.000 \\
A $\times$ T & 15 & 57.652 & 3.843 & 32.923 & 0.000 \\
Error & 48 & 5.604 & 0.117 & & \\
Total & 72 & 202.642 & & & \\
PmMuGST protein levels in the hepatopancreas (PmMuGST/GAPDH) & & \\
Corrected Model & 23 & 715.587 & 31.112 & 719.779 & 0.000 \\
A & 5 & 98.396 & 19.679 & 455.274 & 0.000 \\
T & 3 & 379.652 & 126.551 & 2927.720 & 0.000 \\
A $\times$ T & 15 & 237.538 & 15.836 & 366.359 & 0.000 \\
Error & 48 & 2.057 & 0.043 & & \\
Total & 72 & 1235.345 & & & \\
\hline
\end{tabular}

of the experiment, the transcript levels observed in AFB1 treated groups were all lower than that of D0 group $(P<0.05)$ (Fig. 6a).

\section{Analysis of PmMuGST protein in the hepatopancreas of $P$. monodon after AFB1 exposure}

PmMuGST protein levels in the hepatopancreas of shrimp increased with increase of AFB1 concentration from 0 to $2500 \mu \mathrm{g} / \mathrm{kg}$, and decreased with increased AFB1 exposure times in the range of 14 to 56 days (Fig. 7). Analysis of variance indicated there was significant interaction between the effects of AFB1 dose and exposure time on PmMuGST protein levels $(P<0.05)$ (Table 5). At day14 the levels of PmMuGST protein in the hepatopancreas of shrimp treated with AFB1 were significantly higher than that of the control group $(P<0.05)$ (Fig. 7a). The levels of PmMuGST protein in the D1, D2 and D4 group at 28 days were significantly higher than those of the D0 group (Fig. 7b). After AFB1 exposure for 42 days, the PmMuGST protein levels of shrimp in the groups treated with AFB1 $(100,500,1000$ and $2500 \mu \mathrm{g} / \mathrm{kg})$ revealed significantly higher than that of the control (Fig. 7c). At the end of the experiment, the levels of PmMuGST protein in the D1, D3, D4 and D5 groups were all lower than that of the D0 group $(P<0.05)$ (Fig. $7 d$ ). In sum, the results demonstrated that the PmMuGST protein level was changed after AFB1 exposure. 


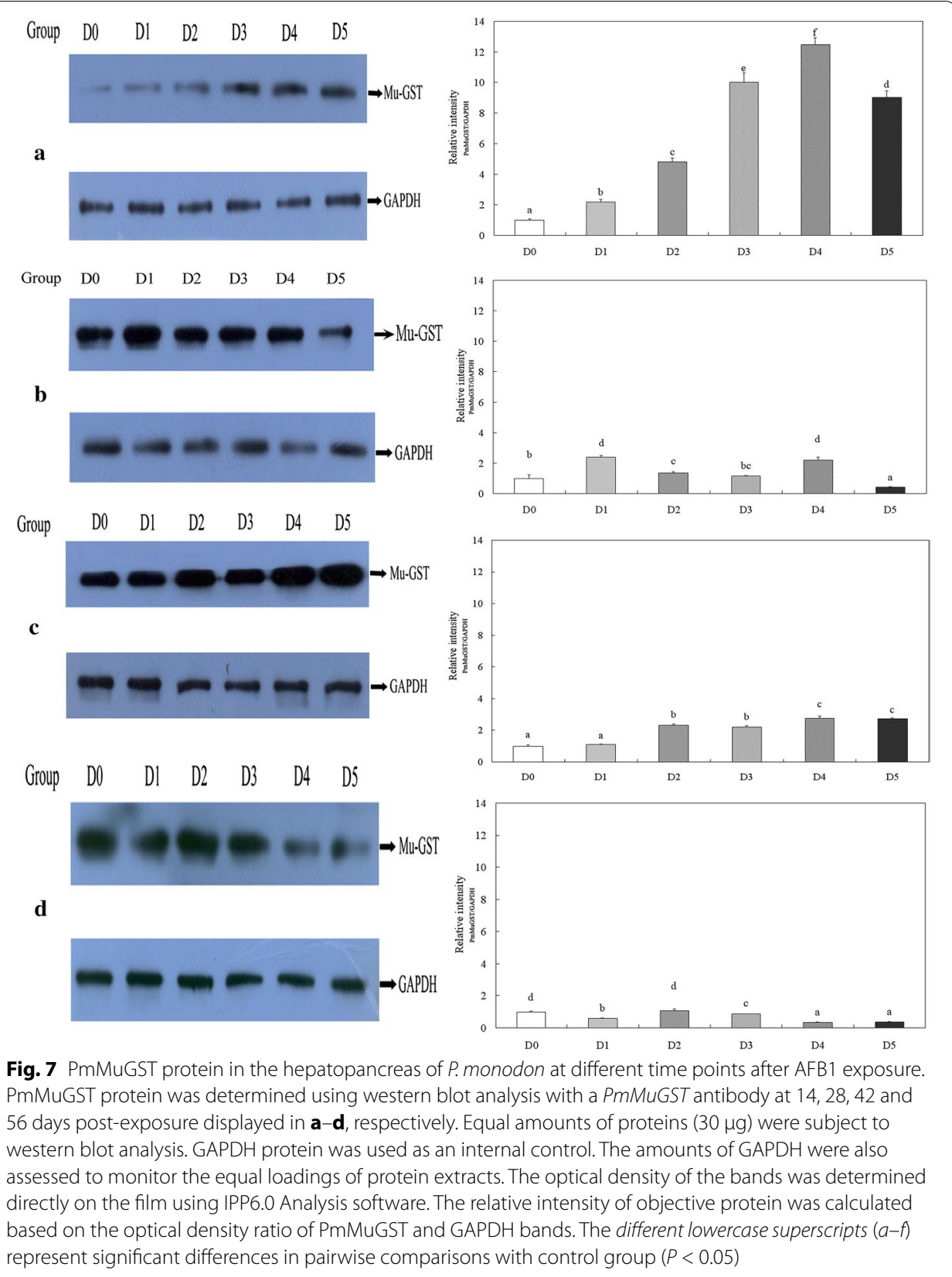

\section{Discussion}

In the present study, a Mu-class GST with a full-length cDNA sequence of 867 bp was cloned from the hepatopancreas of $P$. monodon. The cytosolic GSTs in most organisms are all dimeric with subunit molecular mass varied from 21 to $29 \mathrm{kDa}$ (Mannervik and Danielson 1988). Our predicted molecular weight of PmMuGST was consistent with previous study which reported a Mu class GSTs with an average of $26 \mathrm{kDa}$ of subunit molecular mass in human and rat (Blanchette et al. 2007). GSTs have two classical ligand-binding sites $(\mathrm{G}$ and $\mathrm{H})$ that mediate binding of glutathione and electrophilic xenobiotic substrates to GST, respectively. The G site contains eight highly conserved 
amino acids: $\operatorname{Tyr}^{7}, \operatorname{Trp}^{8}, \operatorname{Trp}^{46}, \operatorname{Lys}^{50}, \mathrm{Asn}^{59}, \mathrm{Leu}^{60}, \mathrm{Gln}^{72}$ and $\mathrm{Ser}^{73}$, which is highly specific for glutathione, is conserved among all GSTs. For most of Mu-GST, Tyr ${ }^{7}$ is the key residue in the G-site. Site-directed mutagenesis studies of the Mu-GST revealed that $\mathrm{Tyr}^{7}$ residue plays an essential role in GST catalysis in promoting and stabilizing the thiolate anion (Wilce and Parker 1994). However, Contreras-Vergara et al. (2008) recently reported that Tyr7 is not critical in L. vannamei, as its mutant has $40 \%$ of the wild type catalytic efficiency. Mu-loop, exclusive to Mu-class GSTs, is an insertion in the sequence compared to other classes of GST (Dirr et al. 1994) and is also a characteristic feature of Mu-class GST. The Mu loop in P. monodon including seven amino acid residues is consistent with the Mu-class GST in T. clavigera (Rhee et al. 2008), which usually occurs in other Mu-class GSTs (Dirr et al. 1994). The last amino acid residue of Mu loop in $P$. monodon was Asp, which is the same as that in the most other species. BLASTP results showed that the deduced amino acid sequence of PmMuGST had high similarity (86 \%) with $\mathrm{Mu}-\mathrm{GST}$ of $L$. vannamei. The sequence alignment and phylogenetic analysis further suggested that $P m M u G S T$ was a member of the Mu-GST family.

The tissue distribution of $P m M u G S T$ mRNA, as well as its response to AFB1 expousure, was investigated. In crustaceans, the distribution of $M u G S T$ in different tissues has been investigated in a variety of organisms, but the results are not similar. The amount of $\mathrm{Mu}$-class GST mRNA is high in the hepatopancreas and gills in white shrimp of L. vannamei (Contreras-Vergara et al. 2004) and is high in gill in rock shell T. clavigera (Rhee et al. 2008). High amounts of Mu GST mRNA were found in the gills and gonad of disk abalone (Wan et al. 2008b). High transcript levels of GSTs in the hepatopancreas have been reported in fish and mollusk species (Gallagher et al. 1995). The PmMuGST mRNA was detected in all of the examined tissues, and the amounts of PmMuGST mRNA in the hepatopancreas and muscle were higher than those in other tissues, which was similar with the reports in L. vannamei and fish (Contreras-Vergara et al. 2004; Gallagher et al. 1995). Interestingly, the obviously high mRNA expression level of PmMuGST was found in the key metabolic center tissues including hepatopancreas and muscle, which suggested the role of PmMuGST in detoxification process.

The results of this experiment indicated that there were no notable differences in survival among shrimp exposed to different AFB1 concentrations ranging from 50 to $2500 \mu \mathrm{g} / \mathrm{kg}$ feed throughout the feeding period of 56 days. Boonyaratpalin et al. (2001) reported a similar finding in P. monodon that diets containing AFB1 at a dosage of 50 to $1000 \mu \mathrm{g} / \mathrm{kg}$ did not cause serious death in shrimp for 56 days. Wang et al. (2012) even concluded that diets containing 400-1600 $\mu \mathrm{g} / \mathrm{kg}$ AFB1 did not increase mortality in L. vannamei. And our study indicated that the black tiger shrimp could tolerate a high dose of dietary AFB1. However, WG of P. monodon in AFB1 treated groups decreased in the present study. And the similar reports were found in P. monodon, and L. vannamei (Boonyaratpalin et al. 2001; Wang et al. 2012). However, we found that WG (185-611 \%) in those previous experiments was much higher than that of WG (90-320 \%) in the present study, suggesting that the initial body weight and different species or other environmental factors were involved in experiments and strengthened the toxic effects of AFB1.

The transcript pattern of PmMuGST was slightly different between the hepatopancreas and muscle, which might be related to the different functions of these tissues in response to the AFB1 exposure. In the present study, PmMuGST transcript levels in 
the hepatopancreas of shrimp decreased with increased AFB1 concentration. Boonyaratpalin et al. (2001) observed that severe degeneration of hepatopancreatic tubules was common in shrimp fed with high concentrations of AFB1 for 8 weeks, as noted by atrophic changes, followed by necrosis of the tubular epithelial cells. Therefore, it was understood that AFB1 toxic effects likely caused the histological changes and severely impaired the normal function of the shrimp's cells, which might be the reason for the reduction of PmMuGST. Moreover, PmMuGST mRNA levels in the hepatopancreas of shrimp increased with AFB1 exposure time. The similar result was reported in $P$. martensii, that PmMGST3 mRNA levels in the hepatopancreas increased to 2.4-fold of the control after exposure to cadmium for 3 days (Chen et al. 2011). However, the transcript level of GSTM (Mu-class GST) in the hepatopancreas of C. cahayensis and the activity of GST in the hepatopancreas of R. philippinarum were significantly decreased after exposure to a high level of microcystin-LR $(100 \mu \mathrm{g} / \mathrm{L})$ and cadmium $(40 \mu \mathrm{g} / \mathrm{L})(\mathrm{Li}$ et al. 2014; Zhang et al. 2013). The transcript profiles of GST mRNA in response to AFB1, cadmium and microcystin-LR exposure indicated that it was inducible and might play an important role in the detoxification response in P. monodon.

In crustaceans, the hepatopancreas is the key metabolic center for the production of reactive oxygen species (ROS) (Duan et al. 2015). The hepatopancreas also plays a major role in the immune defenses of crustaceans (Söderhall and Cerenius 1998), and it is involved in both the synthesis of digestive enzymes and the detoxification of oxenobiotics (Vogt 1994). Therefore, we investigated PmMuGST protein levels by western blot in the hepatopancreas of shrimp exposed to AFB1 exposure. The results showed that PmMuGST protein levels increased with increase of AFB1 concentration from 0 to $2500 \mu \mathrm{g} / \mathrm{kg}$. It may be that PmMuGST mitigates the toxic effects of AFB1 and/or neutralize harmful free radicals generated by AFB1. In lymphocyte-rich mononuclear cells, AFB1 exposure causes the production of ROS and causes biomolecular oxidative damage in broiler lymphocytes (Zimmermann et al. 2014). However, PmMuGST protein levels decreased with increased AFB1 exposure time in the range of 14-56 days, which might related to the lower growth and survival of shrimp. Nevertheless, it was clear that the patterns of PmMuGST mRNA transcript shown in Fig. 6 were seemingly uncorrelated well with the abundance of PmMuGST protein shown in Fig. 7. The absence of mRNA-protein correlation for a subset of investigated genes suggested that the relation between mRNA and protein was not strictly linear but has a more intrinsic and complex dependence, deviating from the classical view referred to as the molecular dogma. Different regulation mechanisms (such as synthesis and degradation rates), acting on both the synthesized mRNA and the synthesized protein, affect the amount of the two molecules differentially. Moreover, the protein translation usually lags the mRNA expression of genes, and the degradation rate of protein is much lower than that of mRNA; thus, there are also cumulative effects. We believe these may be the reasons for the absence of a correlation between mRNA and protein expression.

\section{Conclusion}

In summary, a full-length cDNA sequence of a Mu-class GST was cloned from the black tiger shrimp P. monodon, and it was constitutively expressed in the following tissues: hemocytes, hepatopancreas, muscle, heart, ovary, stomach, eyestalk, and intestine. 
The expression of $P m M u G S T$ in the hepatopancreas and muscle changed dynamically in response to AFB1 exposure, which indicated that PmMuGST was inducible and was involved in the response to AFB1 exposure.

\section{Authors' contributions}

YW and HL designed the experiment. LL (Pearl River Fisheries Research Institute, Chinese Academy of Fishery Sciences) was assistance with tissue preparation. JH, JW, MF (South China Sea Fisheries Institute, Chinese Academy of Fishery Sciences) supported YW to analyze samples. YW analyzed the results and wrote the paper with contributions from the other authors. All authors read and approved the final manuscript.

\section{Author details}

${ }^{1}$ Key Laboratory of Aquatic Product Processing, Ministry of Agriculture, South China Sea Fisheries Research Institute, Chinese Academy of Fishery Sciences, Guangzhou 510300, People's Republic of China. ${ }^{2}$ Pearl River Fisheries Research Institute, Chinese Academy of Fishery Sciences, Guangzhou 510380, Guangdong Province, People's Republic of China.

\section{Acknowledgements}

This research was supported by Guangdong Natural Science Foundation (No. 2014A030310116), Special Scientific Research Funds for Central Non-profit Institutes, South China Sea Fisheries Research Institute, Chinese Academy of Fishery Sciences (No. 2013TS03), and Funds of Key Laboratory of Aquatic Product Processing, Ministry of Agriculture, P. R. China (No. nybjg201205).

\section{Competing interests}

The authors declare that they have no competing interests.

Received: 12 October 2015 Accepted: 20 May 2016

Published online: 22 June 2016

\section{References}

Armstrong RN (1997) Structure, catalytic mechanism, and evolution of the glutathione transferases. Chem Res Toxicol 10:2-18

Arockiaraj J, Gnanam AJ, Palanisamy R, Bhatt P, Kumaresan V, Chaurasia MK, Pasupuleti M, Ramaswamy H, Arasu A, Sathyamoorthi A (2014) A cytosolic glutathione s-transferase, GST-theta from freshwater prawn Macrobrachium rosenbergii: molecular and biochemical properties. Gene 546:437-442

Bathige S, Umasuthan N, Revathy KS, Lee Y, Kim S, Cho MY, Park MA, Whang I, Lee J (2014) A mu class glutathione S-transferase from Manila clam Ruditapes philippinarum (RpGST \& $\mu$ ): cloning, mRNA expression, and conjugation assays. Comp Biochem Phys C 162:85-95

Bergallo M, Astegiano S, Sidoti F, Mantovani S, Cavallo R, Costa C, Segoloni GP (2010) Real-time RT-PCR assay for the quantitation of polyomavirus BK VP1 mRNA levels in urine. Mol Biotechnol 45:82-86

Blanchette B, Feng X, Singh BR (2007) Marine glutathione S-transferases. Mar. Biotechnol 9:513-542

Boonyaratpalin M, Supamattaya K, Verakunpiriya V, Suprasert D (2001) Effects of aflatoxin B1 on growth performance, blood components, immune function and histopathological changes in black tiger shrimp (Penaeus monodon Fabricius). Aquac Res 32:388-398

Boutet I, Tanguy A, Moraga D (2004) Characterisation and expression of four mRNA sequences encoding glutathione S-transferases pi, mu, omega and sigma classes in the Pacific oyster Crassostrea gigas exposed to hydrocarbons and pesticides. Mar Biol 146:53-64

Chen JH, Xiao S, Deng YW, Du XD, Ye ZN (2011) Cloning of a novel glutathione S-transferase 3 (GST3) gene and expression analysis in pearl oyster, Pinctada martensii. Fish Shellfish Immunol 31:823-830

Contreras-Vergara CA, Harris-Valle C, Sotelo-Mundo RR, Yepiz-Plascencia G (2004) A Mu-class glutathione S-transferase from the marine shrimp Litopenaeus vannamei: molecular cloning and active-site structural modeling. J Biochem Mol Toxic 18:245-252

Contreras-Vergara CA, Valenzuela-Soto EM, Arvizu-Flores AA, Sotelo-Mundo RR, Yepiz-Plascencia G (2008) Role of invariant tyrosines in a crustacean class mu glutathione S-transferase from shrimp Litopenaeus vannamei: site-directed mutagenesis of $Y 7$ and $Y 116$. Biochimie 90:968-971

da Rocha MEB, Freire FCO, Maia FEF, Guedes MIF, Rondina D (2014) Mycotoxins and their effects on human and animal health. Food Control 36:159-165

Dirr H, Reinemer P, Huber R (1994) X-ray crystal structures of cytosolic glutathione S-transferases: implications for protein architecture, substrate recognition and catalytic function. Eur J Biochem 220:645-661

Dohnal V, Wu QH, Kuca K (2014) Metabolism of aflatoxins: key enzymes and interindividual as well as interspecies differences. Arch Toxicol 88:1635-1644

Duan Y, Dong H, Wang Y, Zhang Z, Li Z, Zhang J (2015) Effect of desiccation on antioxidant enzyme activities of kuruma shrimp (Marsupenaeus japonicus). S China Fish Sci 11:102-108

Gallagher T, Strom A, George S (1995) The cellular distribution of glutathione S-transferase in plaice: an immunocytochemical study. Mar Envrion Res 39:352-353

Goncalves-Soares D, Zanette J, Yunes JS, Yepiz-Plascencia GM, Bainy ACD (2012) Expression and activity of glutathione S-transferases and catalase in the shrimp Litopenaeus vannamei inoculated with a toxic Microcystis aeruginosa strain. Mar Environ Res 75:54-61

Gopinath R, Raj RP (2009) Histological alterations in the hepatopancreas of Penaeus monodon Fabricius (1798) given aflatoxin B1-incorporated diets. Aquac Res 40:1235-1242 
Gopinath R, Raj RP, George KC, Sanil NK (2012) Ultrastructural changes in the hepatopancreas of Penaeus monodon Fabricius 1798 given aflatoxin B1 diets. Aquac Res 43:32-43

Hayes JD, Judah DJ, McLellan LI, Neal GE (1991) Contribution of the glutathione S-transferases to the mechanisms of resistance to aflatoxin B1. Pharmacol Ther 50:443-472

Hayes JD, Flanagan JU, Jowsey IR (2005) Glutathione transferases. Annu Rev Pharmacol 45:51-88

IARC (1994) Monographs on the evaluation of carcinogenic risks to humans: schistosomes, liver flukes and Helicobacter pylori. International Agency for Research on Cancer, Lyon

Ku PJ, Wu XY, Nie XP, Ou RK, Wang L, Su T, Li YG (2014) Effects of triclosan on the detoxification system in the yellow catfish (Pelteobagrus fulvidraco): expressions of CYP and GST genes and corresponding enzyme activity in phase I, II and antioxidant system. Comp Biochem Phys C 166:105-114

Li L, Liang XF, He S, Li GY, Wen ZY, Cai WJ, Shen D (2014) Transcriptional responses of mu-, pi- and omega-class glutathione S-transferase genes in the hepatopancreas of Cipangopaludina cahayensis exposed to microcystin-LR. Chin Sci Bull 59:3153-3161

Livak KJ, Schmittgen TD (2001) Analysis of relative gene expression data using real-time quantitative PCR and the $2^{-\Delta \Delta C_{T}}$ method. Methods 25:402-408

Mannervik B, Danielson UH (1988) Glutathione transferases_structure and catalytic activity. CRC Crit Rev Biochem Mol 23:283-337

Marroquín-Cardona AG, Johnson NM, Phillips TD, Hayes AW (2014) Mycotoxins in a changing global environment—a review. Food Chem Toxicol 69:220-230

Nadala ECB Jr, Loh PC (1998) A comparative study of three different isolates of white spot virus. Dis Aquat Organ 33:231-234

Niu J, Liu YJ, Tian LX, Mai KS, Yang HJ, Ye CX, Zhu Y (2008) Effects of dietary phospholipid level in cobia (Rachycentron canadum) larvae: growth, survival, plasma lipids and enzymes of lipid metabolism. Fish Physiol Biochem 34:9-17

Ostrowski-Meissner HT, LeaMaster BR, Duerr EO, Walsh WA (1995) Sensitivity of the Pacific white shrimp, Penaeus vannamei, to aflatoxin B1. Aquaculture 131:155-164

Raghavan PR, Zhu X, Lei W, Han D, Yang Y, Xie S (2011) Low levels of Aflatoxin B1 could cause mortalities in juvenile hybrid sturgeon, Acipenser ruthenus male Chi A. baeri female. Aquacult Nutr 17:39-47

Rawal S, Kim JE, Coulombe R (2010) Aflatoxin B1 in poultry: toxicology, metabolism and prevention. Res Vet Sci 89:325-331

Ren HL, Xu DD, Gopalakrishnan S, Qiao K, Huang WB, Wang KJ (2009a) Gene cloning of a sigma class glutathione $S$-transferase from abalone (Haliotis diversicolor) and expression analysis upon bacterial challenge. Dev Comp Immunol 33:980-990

Ren Q, Sun RR, Zhao XF, Wang JX (2009b) A selenium-dependent glutathione peroxidase (Se-GPx) and two glutathione S-transferases (GSTs) from Chinese shrimp (Fenneropenaeus chinensis). Comp Biochem Phys C 149:613-623

Rhee JS, Raisuddin S, Hwang DS, Horiguchi T, Cho HS, Lee JS (2008) A Mu-class glutathione S-transferase (GSTM) from the rock shell Thais clavigera. Comp Biochem Phys C 148:195-203

Sahul Hameed AS, Anilkumar M, Stephen Raj ML, Kunthala J (1998) Studies on the pathogencity of systemic ectodermal and mesodermal beculovirus and its detection in shrimp by immunological methods. Aquaculture 160:31-45

Salazar-Medina AJ, García-Rico L, García-Orozco KD, Valenzuela-Soto E, Contreras-Vergara CA, Arreola R, Arvizu-Flores A, Sotelo-Mundo RR (2010) Inhibition by $\mathrm{Cu}^{2+}$ and $\mathrm{Cd}^{2+}$ of a Mu-class glutathione S-transferase from shrimp Litopenaeus vannamei. J Biochem Mol Biol 24:218-222

Sheehan D, Meade G, Foley VM, Dowd CA (2001) Structure, function and evolution of glutathione transferases: implications for classification of non-mammalian members of an ancient enzyme superfamily. Biochem J 360:1-16

Söderhall K, Cerenius L (1998) Role of prophenoloxidase-activating system in invertebrate immunity. Curr Opin Immunol 10:23-28

Tamura K, Stecher G, Peterson D, Filipski A, Kumar S (2013) MEGA6: molecular evolutionary genetics analysis version 6.0. Mol Biol Evol 30:2725-2729

Tapia-Salazar M, Garcia-Perez OD, Velasquez-Soto RA, Nieto-Lopez MG, Villarreal-Cavazos D, Ricque-Marie D, Cruz-Suarez LE (2012) Growth, feed intake, survival, and histological response of white shrimp Litopenaeus vannamei fed diets containing grains naturally contaminated with aflatoxin. Cienc Mar 38:491-504

Tulayakul P, Sakuda S, Dong KS, Kumagai S (2005) Comparative activities of glutathione-S-transferase and dialdehyde reductase toward aflatoxin B1 in livers of experimental and farm animals. Toxicon 46:204-209

Vogt G (1994) Life-cycle and functional cytology of the hepatopancreas cells of Astacus astacus (Crustacea, Decapoda). Zoomorphology 114:83-101

Wan Q, Whang I, Lee J (2008a) Molecular cloning and characterization of three sigma glutathione S-transferases from disk abalone (Haliotis discus discus). Comp Biochem Phys B 151:257-267

Wan Q, Whang I, Lee J (2008b) Molecular characterization of mu class glutathione-S-transferase from disk abalone (Haliotis discus discus), a potential biomarker of endocrine-disrupting chemicals. Comp Biochem Phys B 150:187-199

Wang Y, Li J, Liu P, Li JT, Zhang Z, Chang ZQ, He YY, Liu DY (2011) The responsive expression of a caspase gene in Chinese shrimp Fenneropenaeus chinensis against pH stress. Aquac Res 42:1214-1230

Wang J, Guo R, Su L, Xia H, Cui M (2012) Toxic effects of aflatoxin B1 on growth performance, biochemical and hepatopancreas microstructure of Liotpenaeus vannamei. J Fish China 36(6):952-957

Wang C, Mu C, Wang C, Zhao J, Wang Q, Wu H (2013) cDNA cloning and mRNA expression of four glutathione S-transferase (GST) genes from Mytilus galloprovincialis. Fish Shellfish Immunol 34:697-703

Wilce MCJ, Parker MW (1994) Structure and function of glutathione S-transferases. BBA Protein Struct Mol 1205:1-18

Zhang L, Wu H, Sun W, Cai W, Jia X (2013) Bioaccumulation and antioxidant responses in Manila clam (Ruditapes philippinarum) under cadmium and copper exposure. S China Fish Sci 9:64-70

Zimmermann CEP, Machado AK, Cadoná FC, Jaques JAS, Schlemmer KB, Lautert C, Cruz IBM, Zanette RA, Leal DBR, Santurio JM (2014) In-vitro cytotoxicity of aflatoxin B1 to broiler lymphocytes of broiler chickens. Rev Bras Cienc Avic $16: 307-312$ 
Zychowski KE, Pohlenz C, Mays T, Romoser A, Hume M, Buentello A, Gatlin lii DM, Phillips TD (2013) The effect of NovaSil dietary supplementation on the growth and health performance of Nile tilapia (Oreochromis niloticus) fed aflatoxin B1 contaminated feed. Aquaculture 376-379:117-123

Submit your manuscript to a SpringerOpen ${ }^{\circ}$ journal and benefit from:

- Convenient online submission

- Rigorous peer review

- Immediate publication on acceptance

- Open access: articles freely available online

- High visibility within the field

- Retaining the copyright to your article

Submit your next manuscript at $\boldsymbol{\nabla}$ springeropen.com 